\title{
USING A GENERALIZED VEGETATION MODEL TO SIMULATE VEGETATION DYNAMICS IN NORTHEASTERN USA
}

\author{
Thomas Hickler, ${ }^{1,+}$ Benjamin Smith, ${ }^{1}$ Martin T. Sykes, ${ }^{1}$ Margaret B. Davis, ${ }^{2}$ \\ SHINYA SugITA, ${ }^{2}$ AND KAREN WALKER ${ }^{3}$ \\ 'Department of Physical Geography and Ecosystems Analysis, Geobiosphere Science Centre, Lund University, \\ Sölvegatan 12, S-223 62 Lund, Sweden \\ ${ }^{2}$ Department of Ecology. Evolution and Behavior. University of Minnesota, 1987 Upper Buford Circle. St. Paul, \\ Minnesota 55108 USA \\ ${ }^{3}$ Department of Forest Resources, University of Minnesota. 1530 Cleveland Avenue North. St. Paul, Minnesota 55108 USA
}

Abstract. Models based on generalized plant physiological theory represent a promising approach for describing vegetation responses to environmental drivers on large scales but must be tested for their ability to reproduce features of real vegetation. We tested the capability of a generalized vegetation model (LPJ-GUESS) to simulate vegetation structural and compositional dynamics under various disturbance regimes at the transition between prairie, northern hardwoods, and boreal forest in the Great Lakes region of the United States.

LPJ-GUESS combines detailed representations of population dynamics as commonly used in forest gap models with the same mechanistic representations of plant physiological processes as adopted by a dynamic global vegetation model (the Lund-Potsdam-Jena [LPJ] model), which has been validated from the stand to the global scale. The model does not require site-specific calibration. The required input data are information on climate, atmospheric $\mathrm{CO}_{2}$ concentration, and soil texture class, as well as information on generally recognized species traits (broad-leaved vs. needle-leaved, general climatic range, two fireresistance classes, shade-tolerance class, and maximum longevity).

Model predictions correspond closely to observed patterns of vegetation dynamics and standing biomass at an old-growth eastern hemlock (Tsuga canadensis)/hardwood forest (Sylvania Wilderness, Michigan), an old-growth forest remnant from the "Great Lakes Pines Forest" (Itasca State Park, Minnesota), and a presettlement savanna (Cedar Creek Natural History Area, Minnesota). At all three sites, disturbance (wind or fire) strongly controls species composition and stand biomass.

The model could be used to simulate vegetation dynamics on a regional basis or under past or future climates and atmospheric $\mathrm{CO}_{2}$ levels, without a need for reparameterization.

Key words: Cedar Creek Natural History Area, Minnesota, USA; ecosystem model; fire disturbance: forest gap models; Great Lakes region. North America; Itasca State Park. Minnesota. USA: LPJ-GUESS; old-growth forest; savanna; Sylvania Wilderness, Michigan, USA; vegetation dynamics.

\section{INTRODUCTION}

The mechanisms underlying vegetation dynamics have concerned ecologists for a long time (e.g., Watt 1947, Connell and Slatyer 1977, Shugart 1984). In the 1970 s, scientists began to integrate the different hypotheses and theories into mathematical models. While ecology has been criticized for becoming an increasingly segregated discipline (e.g., Pickett et al. 1994), this work synthesized knowledge from the fields of plant physiology, population ecology, and ecosystem ecology and tightened the coupling between empirical studies and models. Model development has followed two main streams, which differ in terms of model generality and the spatial scale at which they are applied.

Models of tree population dynamics based on the gapphase dynamic concept (Watt 1947) have been widely

Manuscript received 6 June 2002; revised 17 May 2003; accepted 30 May 2003; final version received 24 June 2003. Corresponding Editor: N. C. Kenkel.

${ }^{4}$ E-mail: Thomas.Hickler@ nateko.lu.se used as tools for exploring theories of ecological succession at small scales, i.e., particular study sites (e.g., Botkin et al. 1972, Prentice et al. 1993, Bugmann 1996, Bugmann et al. 1996, Pacala et al. 1996, Sykes and Prentice 1996). "Gap models" include detailed descriptions of population dynamic processes: establishment, mortality, and effects of resource competition on individual growth. In most gap models, potential growth rates are species-specific and based on correlations between species' geographical distributions and environmental variables (Botkin et al. 1972, Prentice et al. 1993, Bugmann 1996, Bugmann et al. 1996), i.e., on realized niches. This empirical approach does not explicitly treat the physiological mechanisms of photosynthesis, autotrophic respiration, carbon allocation, etc., underlying growth and their responses to environmental conditions. Future changes in climate, atmospheric $\mathrm{CO}_{2}$, and other factors may lead to altered growth rates (IPCC 2001, Norby et al. 2001) and thereby changed realized niches (Loehle and LeBlanc 1996). For these reasons, the inclusion of mechanistic plant physiology in gap models 
has been strongly advocated (Bugmann et al. 1997, Hurtt et al. 1998, Moorcroft et al. 2001), yet relatively little progress has been achieved so far. Empirical data with which to parameterize physiological processes for individual species, such as the biochemistry of photosynthesis, are very limited. In the absence of species-specific data, it may be necessary to base the parameterization of these models on easily recognizable plant traits (Norby et al. 2001).

The family of ecosystem models known as dynamic global vegetation models (DGVMs) has been developed to simulate vegetation dynamics and biogeochemical cycling at scales from the region to the globe (e.g., Foley et al. 1996, Kucharik et al. 2000, Cramer et al. 2001, Sitch et al. 2003; Bachelet et al. 2003). In these models, species are aggregated into broadly defined plant functional types (PFTs), such as "boreal evergreen needle-leaved tree," and, in most models, vegetation growth is modeled based on mechanistic physiological principles that apply in all climates. Population dynamics, competitive interactions among the modeled entities, and successional replacement are represented in less detail than in gap models, and these models have so far not been applied to predict vegetation dynamics on the species level.

In this study, we applied a model (LPJ-GUESS, Smith et al. 2001) that combines detailed representations of population dynamic processes as commonly used in gap models with the same mechanistic representations of plant physiological processes as adopted by a DGVM (the Lund-Potsdam-Jena [LPJ] model; Sitch et al. 2003).

We explore the extent to which the general ecological theory included in LPJ-GUESS can account for observed patterns of vegetation structure and dynamics on the species level at the transition between prairie, northern hardwoods, and boreal forest in the western Great Lakes region of the United States. To our knowledge, this is the first attempt to simulate natural vegetation dynamics on the species level with a model including the same mechanistic representations of plant physiological processes as a generalized model adapted for large-scale analyses.

An aim was to maintain a high level of generality in the combined model, to allow it to be applied on a spatially extensive basis, without a need for additional parameterization. The modeling approach is designed to simulate mean vegetation in a number of grid cells, being part of a larger region. Grid cell size may depend on the resolution of environmental input data, such as climate and soil texture. All species parameters were derived from just a few plant characters that are generally recognized for a large number of species: compared with the global version of the model that uses PFTs, the only additional parameters necessary to model vegetation dynamics on the species level were based on shade-tolerance class, fire resistance, and maximum longevity.
MATERIAL AND METHODS

\section{Study sites}

Sylvania Wilderness. - The primary forests at Sylvania Wilderness (western Upper Michigan, USA, $46^{\circ} 13^{\prime} \mathrm{N}, 89^{\circ} 18^{\prime} \mathrm{W}$ ) are composed of $1-20$ ha patches dominated either by eastern hemlock (Tsuga canadensis) or by hardwoods. The most abundant hardwoods are sugar maple (Acer saccharum), yellow birch (Betula alleghaniensis), and American basswood (Tilia americana) (Davis et al. 1994). K. Walker and S. Sugita (unpublished data) have sampled the overall species composition in a large number of plots spanning a range of compositional types (Fig. 1A).

Windstorms are the main source of disturbance. Storms that typically remove $\sim 10 \%$ of the canopy occur approximately every 50 years, while catastrophic storms that remove $30 \%$ or more have a return time on the scale of centuries (Frelich and Lorimer 1991). Windstorms typically create large multi-tree gaps by trees falling against one another (Davis 2001). The gaps are often colonized by yellow birch and American basswood (Davis et al. 1994).

Itasca State Park.-Itasca State Park (Minnesota, USA, $47^{\circ} 2^{\prime} \mathrm{N}, 95^{\circ} 2^{\prime} \mathrm{W}$ ) is located within the vegetation zone "Great Lakes Pine Forest" of Küchler (1964). Before settlement, the greater part of the forest was dominated by red and white pine (Pinus resinosa, Pinus strobus). Hardwoods (e.g., quaking aspen [Populus tremoiloides], bigtooth aspen [Populus grandidentata], and paper birch [Betula papyrifera]) also covered a substantial part of the park (Hansen et al. 1974).

Fire suppression in the 20th century has impacted forest types by allowing disturbance-dependent pine forests to succeed to more shade-tolerant species such as sugar maple and balsam fir (Abies balsamea) (Tester et al. 1997). Dominance by sugar maple/American basswood and balsam fir/white spruce vegetation would be expected in the total absence of fire disturbance (Buell and Gordon 1945, Westman 1968, Tester et al. 1997). The overall species composition of the old-growth forest within Itasca, based on samples from different vegetation types, is shown in Fig. 2A (K. Walker, S. Sugita, and R. R. Calcote, unpublished data).

Frissel (1973) reconstructed a fire chronology based on fire scars. From 1650 to 1922, any specific location in the park was affected by fire every 22 years on average (Frissel 1973). In a reconstruction of the fire history of Itasca based on charcoal samples, Clark (1988) likewise reported a 22-year mean fire interval, but concluded that large stand-destroying crown fires could occur with an interval of 80-90 years. For approximately $30-60$ years following a major fire, there is generally insufficient fuel to support more than light surface fires (Heinselman 1973).

Cedar Creek Natural History Area.-The Cedar

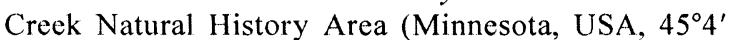


TABLE 1. Summary of the mean climate data at the study sites in the Great Lakes region of the United States for the period 1950-1980 (Thompson et al. 1999) used to drive the model simulations.

\begin{tabular}{lcccc}
\hline \hline \multirow{2}{*}{\multicolumn{1}{c}{ Study site }} & \multicolumn{3}{c}{ Temperature $\left({ }^{\circ} \mathrm{C}\right)$} & $\begin{array}{c}\text { Annual } \\
\text { precipitation } \\
(\mathrm{mm})\end{array}$ \\
\cline { 2 - 5 } & Annual & January & July & \\
\hline Sylvania Wilderness & 4.2 & -12.6 & 18.6 & 817 \\
Itasca State Park & 4.0 & -16.7 & 20.6 & 585 \\
Cedar Creek Natural History Area & 6.1 & -12.7 & 21.6 & 718 \\
\hline
\end{tabular}

$\mathrm{N}, 93^{\circ} 2^{\prime} \mathrm{W}$ ) lies at the prairie-forest boundary. Before settlement, natural fire breaks, such as rivers, were the most important factor controlling vegetation composition in this area. Sites with virtually identical physical characteristics supported different vegetation types because of local differences in fire regimes (Grimm 1984). Very sharp boundaries were found between prairies, fire-tolerant oak woodlands (bur oak [Quercus macrocarpa], red oak [Quercus rubra], white oak [Quercus alba], and pin oak [Quercus ellipsoidalis]), and closed hardwood forests composed of non-fire-tolerant species. Sugar maple, which is very susceptible to fire (A. M. Prasad and L. R. Iverson, 1999-ongoing; available online), ${ }^{5}$ typically dominated areas well protected from fire (Grimm 1984). It is unclear how often the prairies and oak savannas burned before settlement (White 1983), but fire must have occurred frequently to maintain the low tree cover described in historical accounts (Curtis 1959, White 1983).

Pin oak and bur oak are the dominant oak species in the savanna patches at Cedar Creek (Peterson and Reich 2001). In a long-term burning experiment (19642001 ) it has been shown that canopy ingrowth is suppressed and no sapling layer can develop if fire is prescribed with a fire interval of less than three years (Peterson and Reich 2001). After 10 years without fire, the savanna openings are filled with trees and shrubs (Peterson and Reich 2001).

All three study sites experience continental climates. Some features of the climate of each site for the period 1950-1980 are shown in Table 1 (Thompson et al. 1999). Of the three sites, Sylvania has the highest yearly precipitation and Itasca the lowest. The coldest winter temperatures occur at Itasca and the warmest temperatures at Cedar Creek. Cloudiness is similar at all sites.

\section{The model}

We applied the model LPJ-GUESS (Smith et al. 2001), which is similar to a gap model in its representation of tree populations and their dynamics but also includes mechanistic representations of the physiological and biophysical processes underlying plant growth and resource competition among individuals. The model uses the same representations of the processes governing plant carbon balance, allocation of assimilated html)

${ }^{5}$ URL: 〈http://www.fs.fed.us/ne/delaware/atlas/web_atlas carbon, and exchange of water between the soil, plant, and atmosphere as the LPJ DGVM (Sitch et al. 2003). Formulations of population dynamic processes are based on the gap model FORSKA2 (Prentice et al. 1993). The biological entities modeled are individuals for trees and populations for graminoids.

Photosynthesis, canopy conductance, plant maintenance and growth respiration, heterotrophic respiration, transpiration, plant root-weighted uptake of water, and soil hydrology are simulated on a daily time step. Individual tree growth is implemented on an annual time step by allocating the annually accrued net primary productivity (NPP) to leaves, sapwood, and fine roots based on a set of allometric rules (which are influenced by the level of water stress) and by simulating litterfall, fine root turnover, conversion of sapwood to heartwood, and a fixed fractional allocation to reproduction. The vegetation dynamic processes of establishment, mortality, and disturbance are implemented each simulation year.

A modified Farquhar photosynthesis scheme (Farquhar et al. 1980, Collatz et al. 1991, Haxeltine and Prentice 1996) is adopted to calculate carbon assimilation. The amount of carbon fixed by each individual each year is influenced by temperature, atmospheric $\mathrm{CO}_{2}$ concentration, absorbed photosynthetically active radiation (FPAR) and stomatal conductance, the latter being reduced when transpirative demand (Monteith 1995) exceeds a plant-controlled water "supply" rate influenced by soil water content and root distribution, i.e., in the presence of water stress. PAR intercepted by vegetation is partitioned among individuals according to the vertical distribution of their leaf area within the vegetation canopy and light extinction within the canopy.

Overall dynamics for a given region are derived by simulating a number of patches and averaging the results, each patch corresponding in size to the maximum area of influence of one large adult individual on its neighbors. The number of new saplings of a particular species established in each patch each year is drawn at random from the Poisson distribution, with a maximum expectation influenced by a shade-tolerance-class-specific maximum establishment rate and by the "propagule pool," which is related to total allocation to reproduction by the species population among all patches the previous year. Actual establishment is reduced as the canopy closes and hypothetical net primary production (NPP) at the 
TABLE 2. Species parameters used in the model (also see the Appendix).

\begin{tabular}{lc}
\hline \hline a) Longetivity & Details \\
\hline Maximum nonstressed longevity & species-specific (see Appendix)
\end{tabular}

b) Leaf morphology

\begin{tabular}{lcc}
\multicolumn{1}{c}{ Parameter } & Needle-leaved & Broad-leaved \\
\hline Minimum canopy conductance $(\mathrm{mm} / \mathrm{s})$ & 0.3 & 0.5 \\
Leaf turnover rate $\left(\mathrm{yr}^{-1}\right)$ & 0.33 & 1.0 \\
Fine root turnover rate $\left(\mathrm{yr}^{-1}\right)$ & 0.5 & 1.0
\end{tabular}

c) Climatic range

\begin{tabular}{ccc} 
Parameter & Boreal & Temperate \\
\hline Optimal temperature range for photosynthesis $\left({ }^{\circ} \mathrm{C}\right)$ & $10-25$ & $15-25$
\end{tabular}

d) Shade tolerance

\begin{tabular}{lcccc} 
Parameter & Very tolerant & Tolerant & Intermediate & Intolerant \\
\hline Sapwood to heartwood conversion rate $\left(\mathrm{yr}^{-1}\right)$ & 0.1 & 0.12 & 0.15 & 0.2 \\
Growth efficiency threshold $\left(\mathrm{g} \mathrm{C} \cdot \mathrm{m}^{-2} \cdot \mathrm{yr}^{-1}\right)$ & 119 & 136 & 153 & 170 \\
Maximum establishment rate $\left(\mathrm{saplings} \cdot \mathrm{yr}^{-1} \cdot \mathrm{patch}^{-1}\right) \dagger$ & 1.0 & 2.0 & 3.0 & 4.0 \\
Minimum PAR at forest floor for establishment $\left(\mathrm{W} / \mathrm{m}^{2}\right)_{\dagger}^{\dagger}$ & 1.0 & 3.0 & 5.0 & 7.0 \\
Recruitment shape parameter $\$$ & 0.3 & 1.0 & 2.0 & 3.0
\end{tabular}

e) Fire sensitivity

Parameter

Species with fire resistance\|

Remaining species

\begin{tabular}{l}
\hline Fire resistance shape parameter 1 \\
\hline$\dagger$ Relative values; total maximum background establishment of all species together was in the range 0.068 saplings $/ \mathrm{m}^{2}$ (all \\
shade-tolerant species) to 0.272 saplings $/ \mathrm{m}^{2}$ (all shade-intolerant species). \\
$\ddagger$ PAR, photosynthetically active radiation. \\
$\S$ High values indicate strongly reduced establishment as growth conditions at the forest floor become unfavorable as a \\
result of low PAR levels (Fulton 1991$)$. \\
$\|$ White oak, bur oak, northern red oak, white pine, and red pine. \\
I Definitions: $p_{\text {surv }}=1-\left\{1 /\left[1+(D / R)^{1.5}\right]+0.05\right\}$, with $p_{\text {surv }}=$ individual probability of surviving a surface fire, $D=$ \\
stem diameter, and $R=$ fire resistance shape parameter.
\end{tabular}

forest floor decreases as a result of reduced PAR levels at the forest floor (as a surrogate for juvenile growth rates; Fulton 1991). No saplings are established in a given patch if forest-floor PAR falls below a shadetolerance-class-specific threshold, which is higher for more light-demanding species. All individuals within a tree cohort (i.e., a group of individuals of the same species establishing in the same year) are assumed to be identical in size and response to driving conditions.

The expected mortality within each tree cohort each year is the sum of a constant background rate, inversely related to maximum nonstressed longevity (Shugart 1984), and a stress-related rate, which increases steeply as five-year mean growth efficiency (NPP per unit leaf area) declines and approaches a shade-tolerance-classspecific threshold. Actual mortality is drawn at random from a normal distribution whose mean is the expected fraction of individuals killed.

A complete description of LPJ-GUESS is given by Smith et al. (2001); further details of the physiological, biophysical, and biogeochemical components of the model are given by Sitch et al. (2003).

\section{Parameter estimation}

Species parameters (see Table 2 and Appendix) were derived as follows. Maximum nonstressed longevity was the only species-specific parameter, values for which were taken from A. M. Prasad and L. R. Iverson (1999-ongoing; available online $)^{5}$ and Burns and Honkala (1990). All other species parameters were based on generally recognized plant characteristics: leaf morphology (broad-leaved or needle-leaved), climatic ranges (temperate or boreal), fire resistance (resistant or not), and four shade-tolerance classes (intolerant of shade, intermediate, tolerant, very tolerant) as given in A. M. Prasad and L. R. Iverson (1999-ongoing; available online) $)^{5}$ and Burns and Honkala (1990). Species parameters related to needle morphology and climatic range were taken as for the PFT corresponding to the respective species in the global version of the model LPJ (Sitch et al. 2003).

Trees that are known to be resistant to fire (white oak [Quercus alba], bur oak, northern red oak [Q. rub$r a]$, white pine, and red pine) were assigned a higher resistance to surface fires than the remaining species. Species parameters related to shade tolerance class were based on the hypothesis that tree species face a strategic trade-off: species can either allocate to fast growth and high maximum recruitment or to functions that permit survival at low growth rates resulting from intense shading by neighbors. The existence of a general trade-off between investment into survival under 
competition on the one hand and reproduction on the other has been asserted by several authors (e.g., Tilman 1994, Pacala et al. 1996, Ehrlen and van Groenendael 1998). Trade-offs between fast growth and survival under shade were shown for eastern hemlock/American beech (Fagus grandifolia)-dominated stands in the northeastern United States by Pacala et al. (1996), who hypothesized that species cannot allocate both to rapid growth and to functions that permit survival at low growth rates (Kobe et al. 1995).

In LPJ-GUESS, this trade-off is implemented as follows (Smith et al. 2001; see Table 2 for parameter values). Trees with low shade tolerance are assigned a higher yearly conversion rate of sapwood to heartwood (leading to fast growth) and a higher maximum establishment rate compared to shade-tolerant species. Shade-intolerant species are assumed to suffer greater mortality under light stress than shade-tolerant species and are therefore assigned a higher growth-efficiency threshold for stress mortality. Finally, the decline in sapling recruitment with decreasing potential forest floor NPP (Fulton 1991) is steeper for shade-intolerant than for shade-tolerant species.

\section{Modeling protocol}

The model was run from "bare ground" with 20 replicate patches for 1000 simulation years, the maximum required for vegetation biomass to saturate in the absence of disturbances. The climate data set of Thompson et al. (1999) was used to drive the simulations, utilizing mean monthly temperature, precipitation, and cloudiness values (Table 1). Daily values for the climatic drivers were derived by linear interpolation between monthly values. Mean soil texture was also specified for each study site (Jordan 1973, Grigal et al. 1974, Hansen et al. 1974). Atmospheric $\mathrm{CO}_{2}$ concentration was set to a global mean value of 340 ppmv.

For Sylvania and Itasca, the model was run with the species recorded by K. Walker, S. Sugita, and R. R. Calcote (unpublished data). For Cedar Creek, the model was run with the species that could potentially grow at Cedar Creek according to their geographical distribution as given by Burns and Honkala (1990). Tamarack (Larix laricina) was excluded as it is known to be restricted to wooded wetlands. Different species of Populus were not distinguished. Consistent with the very similar ecology of the four Populus species that grow at the study sites (Burns and Honkala 1990; A. M. Prasad and L. R. Iverson, 1999-ongoing; available online), ${ }^{5}$ the model was run with one generic Populus $\mathrm{sp}$., which represents bigtooth aspen and quaking aspen at Sylvania (K. Walker, personal observation); bigtooth aspen, quaking aspen, and balsam popular (Populus balsamifera) at Itasca (K. Walker, personal observation); and bigtooth aspen, quaking aspen, and eastern cottonwood (Populus deltoides) at Cedar Creek (Burns and Honkala 1990).
Aboveground biomass of each tree species was calculated as a constant fraction of the simulated total biomass for the species. This fraction was assumed to be 0.76 , the mean for boreal forests, temperate coniferous forests, and temperate deciduous forests given by Jackson et al. (1996). Graminoids were assumed to allocate $70 \%$ of their biomass to belowground structures.

\section{Fire and wind disturbance}

At Itasca and Cedar Creek, the occurrence of fire was modeled stochastically, actual fire frequencies being drawn at random from a normal distribution about the expected frequency. Expected fire return times were prescribed according to observations from each site; 22 years at Itasca, following Frissel (1973); 1, 3, 5, and 10 years at Cedar Creek, in order to include a number of possible presettlement fire regimes (Curtis 1959, White 1983, Peterson and Reich 2001). The Weibull function (Johnson and Gutsell 1994) was used to calculate the expected temporal pattern of fire occurrence: the probability of fire occurrence increases in an S-shaped manner with time since the last fire, in accordance with the assumption that fire probability increases as the fuel available for combustion accumulates (Johnson and Gutsell 1994).

If a fire occurred, it was assumed to become an intensive crown fire only if fuel biomass in terms of aboveground deadwood (litter and heartwood) was $5 \mathrm{~kg} / \mathrm{m}^{2}$ or more and stand tree leaf area index (LAI, leaf area per unit ground area), as a measure of crown density, was higher than 2.5. Fuel loading and crown density are commonly used variables to model fire effects, in particular if fires occur either as surface or crown fires (e.g., Johnson 1992, Van Wagner 1993), but the quantitative basis for defining general thresholds for the occurrence of crown fires is lacking (Keyes and O'Hara 2002). We consider the threshold values used here to be an expert estimate based on the available literature. Simulated fire behavior (surface vs. crown fire) with these parameter values corresponded closely to observations: at Itasca, crown fires were simulated to occur approximately with the same frequency as reconstructed by Clark (1988), and fires at Cedar Creek were simulated to occur as surface fires (Reich et al. 2001).

If a crown fire occurred, all trees in the patch were killed and their aboveground biomass removed. If a surface fire occurred, the proportion of individuals of a given cohort surviving the fire was drawn at random from a normal distribution centered on an expected proportion influenced by the species-specific fire resistance shape parameter and individual stem diameter (Table 2).

At Sylvania, the occurrence of windstorms removing $\sim 10 \%$ of the canopy was modeled stochastically, actual wind frequencies being drawn at random from a normal distribution about the expected frequency. Expected return times of wind disturbance were prescribed according to observations from Davis (2001), 


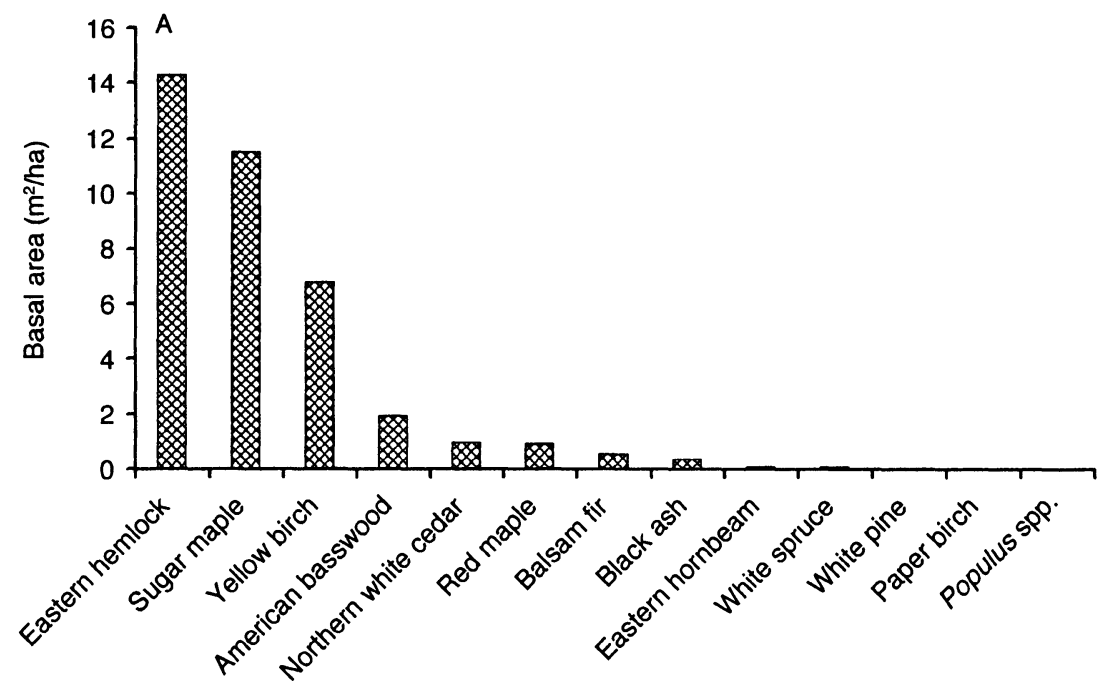

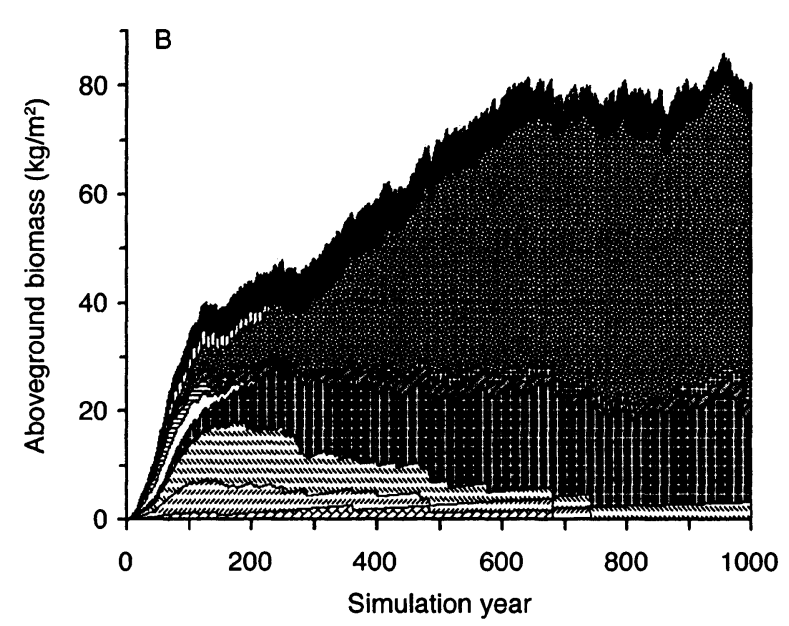

American basswood

- Balsam fir

m Black ash

Eastern hemlock

표 Eastern hornbeam

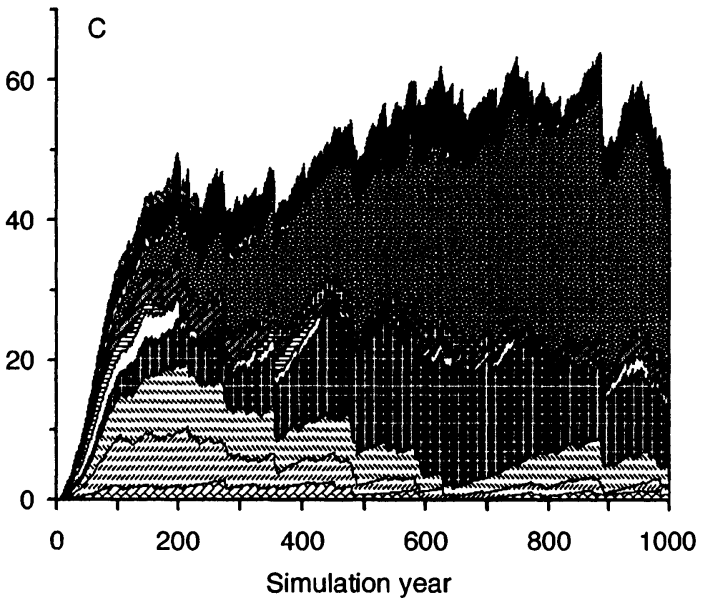

Northern white cedar

目 Paper birch

$\square$ Populus spp.

Red maple
Sugar maple

White pine

White spruce

Yellow birch

FIG. 1. (A) Observed vegetation composition and (B) simulated vegetation dynamics at Sylvania Wilderness, western Upper Michigan, USA, in the absence of wind disturbance and $(C)$ with wind disturbance.

with, on average, one windstorm occurring every 50 years. If a windstorm occurred in a given patch, the patch was cleared with a probability of 0.1 (all trees removed). It was thus assumed that windstorms create large gaps rather than killing individual trees (Davis 2001).

\section{RESULTS \\ Sylvania}

The model predicts species of low or intermediate shade tolerance (paper birch, white pine, white spruce [Picea glauca], yellow birch, Populus spp.) to dominate for approximately 200 years, and species that are either tolerant or very tolerant of shade (eastern hemlock, sugar maple, balsam fir, northern white-cedar [Thuja occidentalis], American basswood and eastern hornbeam [Ostrya virginiana]) to increase in biomass as succession proceeds (Fig. 1B, C).

Without wind disturbance, the late-successional forest is composed of shade-tolerant species (mainly eastern hemlock, sugar maple, and balsam fir) and white pine (Fig. 1B). With wind disturbance, all species occur at least occasionally during the entire simulation period (Fig. 1C). The model underestimates the importance of yellow birch and American basswood as components of the late-successional forest. 
TABLE 3. Comparison of simulated aboveground stand biomass with estimates for similar vegetation in the same region.

\begin{tabular}{lccc}
\hline \multicolumn{1}{c}{$\begin{array}{c}\text { Study site and } \\
\text { disturbance regime }\end{array}$} & $\begin{array}{c}\text { Simulated } \\
\text { biomass } \\
\left(\mathrm{kg} / \mathrm{m}^{2}\right)\end{array}$ & $\begin{array}{c}\text { Estimated } \\
\text { stand biomass } \\
\left(\mathrm{kg} / \mathrm{m}^{2}\right)\end{array}$ & Source \\
\hline $\begin{array}{l}\text { Sylvania Wilderness } \\
\text { With wind disturbance } \\
\text { Without wind disturbance }\end{array}$ & $\approx 60$ & 57.2 & Crow (1978) \\
$\begin{array}{l}\text { Itasca State Park } \\
\text { With natural fire regime }\end{array}$ & $\approx 4.1$ & $\begin{array}{c}6.34 \pm 3.67 \\
28.4-32.5\end{array}$ & $\begin{array}{c}\text { Botkin and Simpson (1990) } \\
\text { In the absence of fire }\end{array}$ \\
$\begin{array}{l}\text { Cedar Creek Natural History } \text { Area } \\
\text { In the absence of fire }\end{array}$ & $\approx 37$ & $28.4-32.5$ & Mroz et al. (1985) \\
\hline
\end{tabular}

Simulated aboveground tree biomass reaches a maximum of $\sim 55 \mathrm{~kg} / \mathrm{m}^{2}$ after 600 years with wind disturbance, and $\sim 80 \mathrm{~kg} / \mathrm{m}^{2}$ after 600 years in the absence of wind disturbance (Fig. 1B, C). The first estimate corresponds closely to an estimate by Crow (1978), who projected an upper limit of $57.2 \mathrm{~kg} / \mathrm{m}^{2}$ for oldgrowth eastern hemlock/hardwood stands (Table 3 ).

\section{Itasca}

The model predicts dominance of white and red pine with frequently occurring fire disturbance and after 80 years in the absence of fire disturbance (Fig. 2B). With fire disturbance, the forest is mainly composed of species with low or intermediate shade tolerance (red pine, white pine, jack pine, and paper birch; Fig. 2B). In the absence of fire disturbance during the last 80 years of the simulation period, shade-tolerant species (e.g., sugar maple) increase in importance relative to shade-intolerant species (e.g., red pine) (Fig. 2B).

Fire disturbance strongly controls simulated stand biomass, which rapidly increases from, on average, 4.1 $\mathrm{kg} / \mathrm{m}^{2}$ during the first 920 years of simulation to 21.7 $\mathrm{kg} / \mathrm{m}^{2}$ after 80 years without fires. Botkin and Simpson (1990) estimated a mean standing crop of $6.34 \pm 3.67$ $\mathrm{kg} / \mathrm{m}^{2}$ for boreal forests immediately north of Itasca, including a variety of stands with different disturbance histories (Table 3).

In the absence of fire disturbance, the model predicts replacement of the pines by sugar maple and balsam fir (Fig. 2C). Modeled stand biomass reaches a maximum of $\sim 37 \mathrm{~kg} / \mathrm{m}^{2}$ after 200 years, which is slightly higher than the estimate of $28.4-32.5 \mathrm{~kg} / \mathrm{m}^{2}$ by Mroz et al. (1985; Table 3), based on two sugar maple stands. However, Mroz et al. (1985) suggested that higher biomass could be achieved under the same climatic conditions if soil conditions were more favorable, rooting depth having been limited by shallow soils at one site and fragipan at the other.

\section{Cedar Creek}

With fire intervals of five or 10 years, the model predicts a hardwood savanna dominated by oaks (Fig. $3 \mathrm{~A}$, Table 4 ). When fire is prescribed to occur every year, a treeless prairie is predicted (not shown). With a fire interval of three years, an open savanna with a very small tree component is predicted (Fig. 3A, Table $4)$. In the absence of fire, the model predicts dominance of sugar maple (Fig. 3B).

With a fire interval of 10 years, aboveground biomass is comparable to a closed forest (Table 4), but most of the biomass is concentrated in a few large old trees. Hence, simulated tree LAI is low (Table 4), and simulated canopy density is rarely sufficient to carry crown fires. These effects of surface fires on vegetation structure would be expected because fire mortality of many fire-resistant oak trees is concentrated in early life stages, while older trees commonly survive surface fires because of their thick bark (White 1983, Peterson and Reich 2001).

In the absence of fire, the model predicts aboveground biomass to reach a maximum of $\sim 50 \mathrm{~kg} / \mathrm{m}^{2}$, which is about $65 \%$ higher than the value estimated by Mroz et al. (1985) for sugar maple stands with limited rooting depth in the western Great Lakes region (Table 3 ).

\section{DISCUSSION}

LPJ-GUESS successfully predicts the dominant species at Sylvania Wilderness and observed patterns of succession at Itasca State Park and Cedar Creek Natural History Area under natural fire regimes and in the absence of fire disturbance. Simulated equilibrium aboveground biomass predicted for Sylvania and Itasca is comparable to observations.

Simulated succession follows the same pattern as generally observed in temperate and boreal forests of North America: in the absence of external disturbance, succession proceeds from light-demanding, fast-growing, short-lived pioneer species to shade-tolerant, slowgrowing, long-lived species with low mortality under intense light competition (Bergeron and Dubuc 1989, Pacala et al. 1996). However, species replacement is not solely determined by shade tolerance and longevity. It is also influenced by differences in growth rates, which depend on functional characteristics related to leaf morphology and climatic range (see Table 2), the 

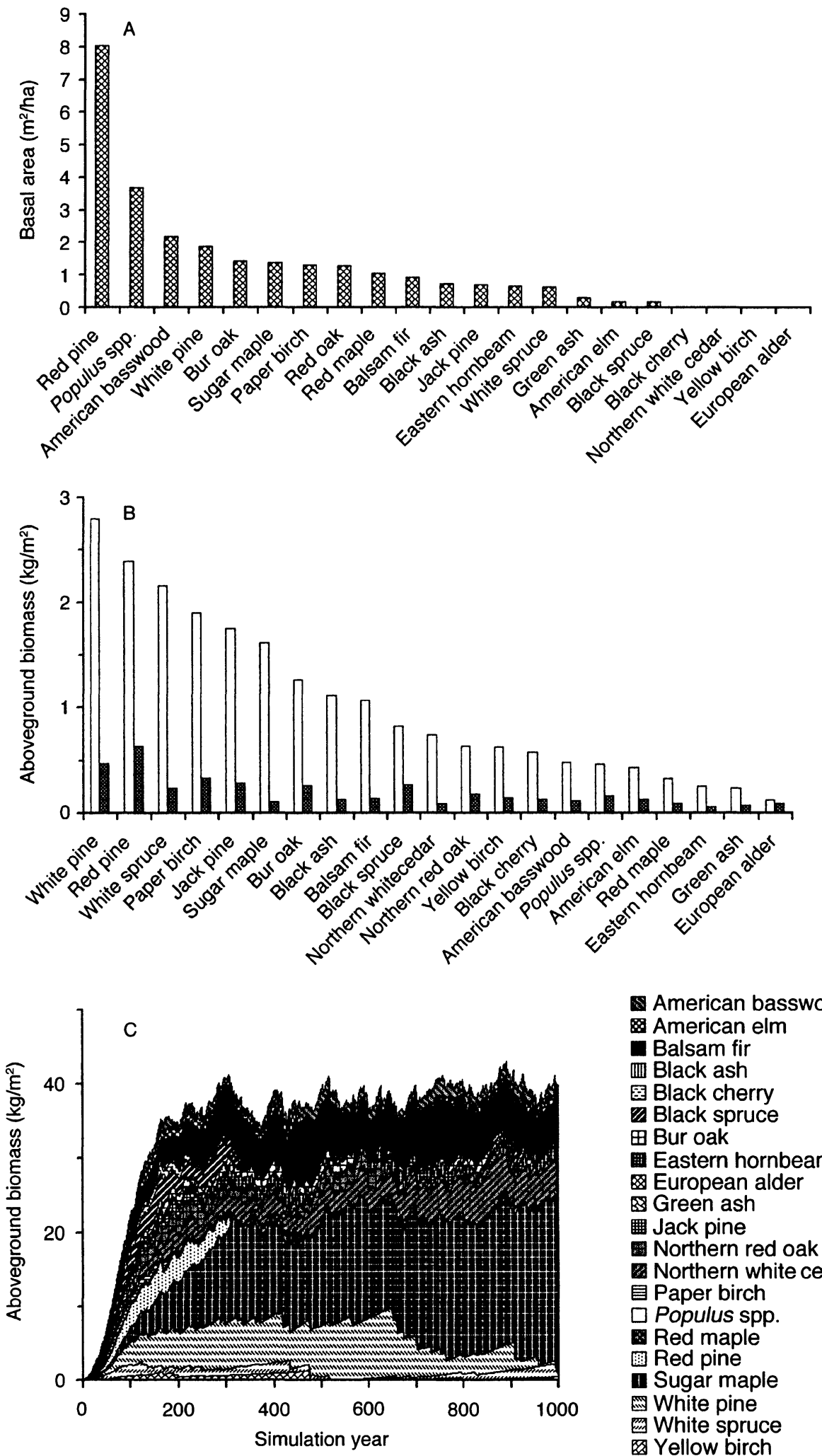

American basswood

American elm

Balsam fir

min Black ash

图 Black cherry

Black spruce

$\boxplus$ Bur oak

Eastern hornbeam

$\otimes$ European alder

Green ash

典 Jack pine

Northern red oak

Northern white cedar

目 Paper birch

$\square$ Populus spp.

Red maple

国 Red pine

- Sugar maple

White pine

White spruce

Yellow birch

FIG. 2. Observed and simulated vegetation at Itasca State Park, Minnesota, USA: (A) observed composition; (B) simulated mean aboveground biomass of each species over 920 simulation years with frequent fire disturbance (hatched bars) and after 920 years with fire disturbance followed by 80 years in the absence of fire disturbance (white bars); (C) simulated vegetation development in the absence of fire disturbance. 

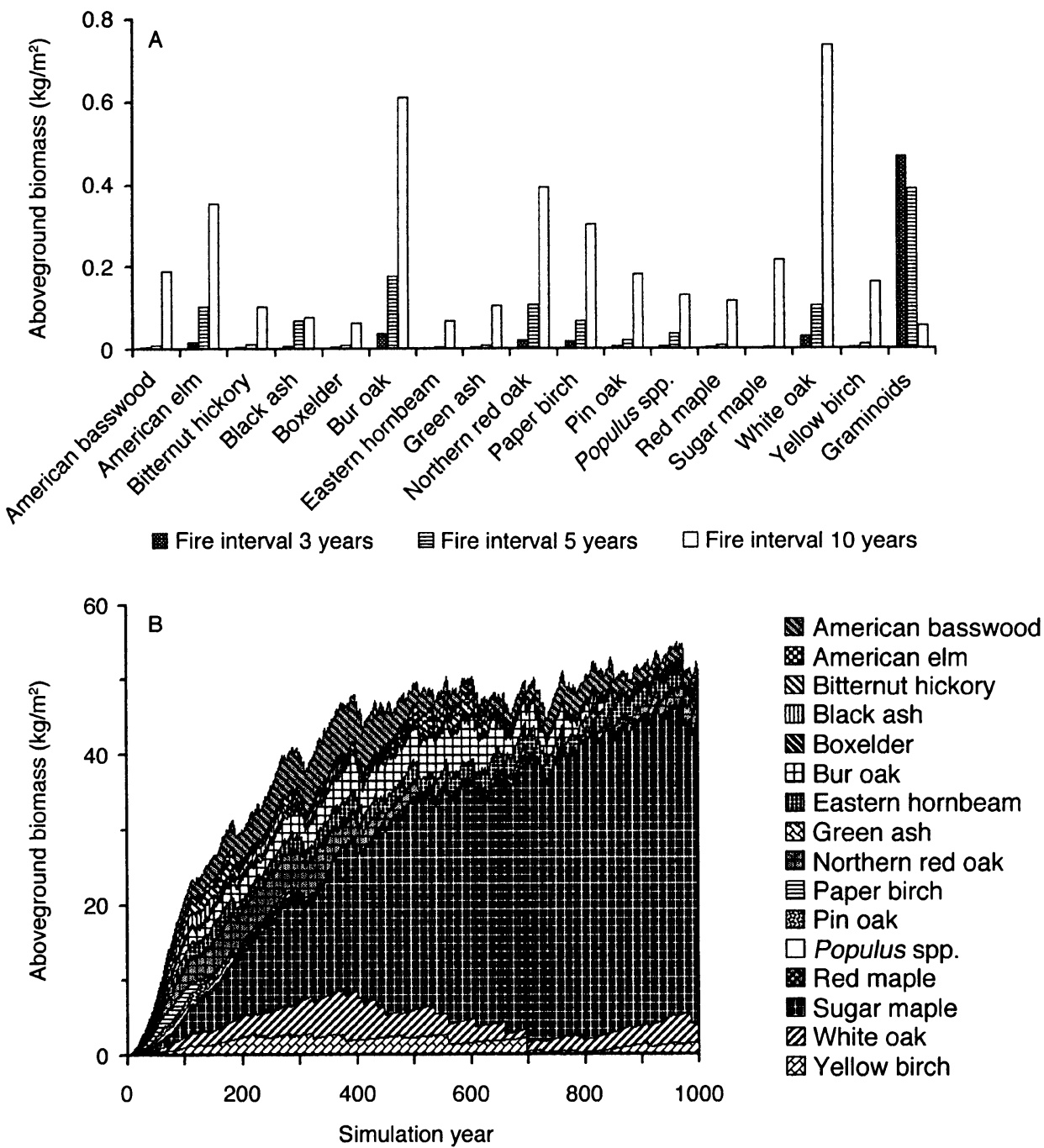

FIG. 3. (A) Simulated equilibrium vegetation composition at Cedar Creek Natural History Area, Minnesota, USA, assuming three-, five-, or 10-year mean fire intervals. (B) Simulated vegetation development in the absence of fire disturbance.

prevailing environmental conditions, as well as fire resistance.

The results for Sylvania suggest that creation of large gaps by wind disturbance is an important mechanism controlling stand biomass and for maintaining a mix-

TABLE 4. Simulated vegetation structure at Cedar Creek for different expected fire intervals. Values are averaged over 1000 simulation years.

\begin{tabular}{ccc}
\hline \hline $\begin{array}{c}\text { Fire } \\
\text { interval }(\mathrm{yr})\end{array}$ & Tree LAI $\dagger$ & $\begin{array}{c}\text { Tree aboveground } \\
\text { biomass } \\
\left(\mathrm{kg} / \mathrm{m}^{2}\right)\end{array}$ \\
\hline 3 & 0.36 & 0.17 \\
5 & 0.56 & 0.75 \\
10 & 1.53 & 3.81
\end{tabular}

$\dagger \mathrm{LAI}=$ leaf area index (ratio of leaf area to ground area covered). ture of shade-tolerant trees and gap species. However, the model does not predict the same gap species as observed (yellow birch and American basswood). Instead, species such as white pine, white spruce, and black ash are most strongly advantaged by gap formation in the simulations. White pine regeneration may be more dependent on fire disturbance than assumed in the model used here. Exposure of mineral soil seed beds after fire favors the establishment of white pine (Frissel 1973, Frelich 2002).

The simulated strong control of stand biomass by fire disturbance at Itasca supports the conclusion of Botkin and Simpson (1990) that estimates of boreal forest biomass that do not take into account fire disturbances are too high to be representative. Based on a survey of 760 plots throughout the boreal forest in North America, including areas with significant dis- 
turbance, Botkin and Simpson (1990) estimated a mean standing biomass of $4.18 \pm 1.01 \mathrm{~kg} / \mathrm{m}^{2}$ for the whole of the boreal forest and $6.34 \pm 3.67 \mathrm{~kg} / \mathrm{m}^{2}$ for the region of boreal forest immediately north of Itasca. Earlier estimates, which were based on investigations in particular forest stands with relatively little disturbance, were in the range $12-18 \mathrm{~kg} / \mathrm{m}^{2}$ (Ajtay et al. 1979).

The high predicted stand biomass at Cedar Creek in the absence of fire disturbance is consistent with Grimm's (1984) hypothesis that the presence of a mosaic of savanna and forest in this area is not a primary result of direct climatic effects on the vegetation; climatic conditions do not limit the growth of dense forests in this area according to the model. Rather, the simulations suggest that fire may be the single most important factor explaining the mosaic of vegetation types in the area (Grimm 1984), while fire frequencies are influenced not only by climate, but also by fuel type and load, landscape structure, including the presence of fire breaks, and human activity.

The strong control of simulated stand biomass by disturbance at all three study sites confirms that carbon storage in the Lake States is highly related to stand age and that forest management has a large potential to increase carbon storage in forests, e.g., by reducing fire frequency (Grigal and Ohmann 1992). These results show that modeling studies in the study area must treat the different disturbance agents explicitly.

\section{Limitations of the model}

Yellow birch, American basswood, and the three species of Populus growing at Itasca (bigtooth aspen, quaking aspen, and balsam popular) can reproduce vigorously by sprouting after disturbance (Burns and Honkala 1990; A. M. Prasad and L. R. Iverson, 1999ongoing; available online). ${ }^{5}$ Vegetative reproduction by sprouting is not included in LPJ-GUESS. The model underestimates the abundance of these species, and this might be because their abundance in nature is influenced by their ability to resprout or other processes that are not included in the model. The high actual abundance of Populus spp. at Itasca may also be a result of wind disturbance, which probably favors early successional species like Populus spp.: in 1953, 6 ha of forest west of Lake Itasca were cleared by a blow-down (Hansen et al. 1974). Because of the scarcity of data on the frequency and effects of wind disturbance at this site, the model was run without wind disturbance.

The model overestimates the actual abundance of white pine at Itasca. White pine has recently declined at this site because of a number of factors that are not included in the simulations: Since the establishment of the park (1891), pine regeneration has been largely suppressed owing to large deer populations. White pine has also been impacted by the prevalence of the pathogen white pine blister rust (Hansen et al. 1974), and the species is particularly vulnerable to windstorms (Tester et al. 1997).
The aim of this study was to simulate average vegetation at the study sites, as influenced by climate, average soil texture, gap dynamics, and disturbance by wind and fire. Between-patch variability as a result of stochastic variation in establishment, mortality, fire, and wind disturbance was not considered, although it is a feature of the natural vegetation and is simulated by the model.

Small-scale heterogeneity in soil texture and nutritional status are thought to influence the competitive balance between sugar maple/American basswood and white spruce/balsam fir vegetation types at Itasca in the absence of fire disturbance (Hansen et al. 1974, Tester et al. 1997). However, between-patch environmental heterogeneity and species-specific nutrient requirements were not included in the model simulations, in part because the necessary process understanding and data are quite limited (Reynolds et al. 2001). Species differences in nutrient response could only have been included by adopting empirical rules, and this was deliberately avoided. At Sylvania, the mechanisms leading to the patchy pattern of vegetation at the study sites are either not well understood (Pastor and Broschart 1990) or include processes that are difficult to implement without a loss of model generality, for example, the effect of mature trees on seedbed conditions (Frelich et al. 1993).

As the model does not treat processes peculiar to wetlands, such as waterlogging, it would be unsuitable for simulating vegetation in regions in which wetlands are an important landscape component.

\section{Model applicability}

An earlier version of the model applied here successfully reproduced the PFT composition of a number of old-growth forests (Badeck et al. 2001) and potential vegetation (Smith et al. 2001) across Europe. Responses of modeled net ecosystem carbon exchange (NEE) to seasonal and interannual variation in climate have been validated against eddy-covariance measurements over a range of European forests (Valentini et al. 2000; P. Morales, B. Smith, and M. T. Sykes, unpublished data), while the response of NPP to elevated atmospheric $\mathrm{CO}_{2}$ has been validated by comparison with results from the Duke Forest Free Air Carbon Dioxide Enrichment (FACE) experiment (DeLucia et al. 1999; T. Hickler, I. C. Prentice, B. Smith, and M. T. Sykes, unpublished manuscript). This study shows that LPJGUESS also can be applied to simulate vegetation dynamics on the species level. As the model does not require site-specific calibration, it would be possible to test the capability of the model to predict vegetation dynamics at additional sites or on a regional scale without altering the internal parameterization. Since plant growth is modeled mechanistically, the model can also be applied to project dynamics under changed environmental conditions, such as increased temperatures and atmospheric $\mathrm{CO}_{2}$. 


\section{ACKNOWLEDGMENTS}

We acknowledge with thanks funding for the MORPHEUS project from the National Science Foundation NSF-ATM 9709633 and the Max-Planck Institute of Biogeochemistry Jena, Germany, and helpful comments from two anonymous reviewers.

\section{Literature Cited}

Ajtay, G. L., P. Ketner, and P. Duvigneaud. 1979. Terrestrial primary production and phytomass. Pages 129-182 in B. Bolin, E. T. Degens, S. Kempe, and P. Ketner, editors. The global carbon cycle. John Wiley and Sons, New York, New York, USA

Bachelet, D., R. P. Neilson, T. Hickler, R. J. Drapek, J. M. Lenihan, M. T. Sykes, B. Smith, S. Sitch, and K. Thonicke. 2003. Simulating past and future dynamics of natural ecosystems in the United States. Global Biochemical Cycles 17:1045

Badeck, F. W., H. K. Lischke, H. Bugmann, T. Hickler, K. Hönninger, P. Lasch, M. J. Lexer, F. Mouillot, J. Schaber, and B. Smith. 2001. Tree species composition in European pristine forests. Comparison of stand data to model predictions. Climatic Change 51:307-347.

Bergeron, Y., and M. Dubuc. 1989. Succession in the southern part of the Canadian forest. Vegetatio 79:51-63.

Botkin, D. B., J. F. Janak, and J. R. Wallis. 1972. Some ecological consequences of a computer model of forest growth. Journal of Ecology 60:849-872.

Botkin, D. B., and L. G. Simpson. 1990. Biomass of the North American boreal forest: a step toward accurate global measures. Biogeochemistry 9:161-174.

Buell, M. F., and W. E. Gordon. 1945. Hardwood-conifer forest contact zone in Itasca Park, Minnesota. American Midland Naturalist 34:433-439.

Bugmann, H. K. M. 1996. A simplified forest model to study species composition along climate gradients. Ecology 77: 2055-2074.

Bugmann, H. K. M., R. Grote, P. Lasch, M. Lindner, and F. Suckow. 1997. A new forest gap model to study the effects of environmental change on forest structure and functioning. Pages 255-261 in G. M. J. Mohren, K. Kramer, and S. Sebaté, editors. Impacts of global change on tree physiology and forest ecosystems. Kluwer Academic, Dordrecht. The Netherlands

Bugmann, H. K. M., X. Yan, M. T. Sykes, P. Martin, M. Lindner, P. V. Desanker, and S. G. Cumming. 1996. A comparison of forest gap models: model structure and behaviour. Climatic Change 34:289-313.

Burns, R. M., and R. B. Honkala, technical coordinators. 1990. Sylvics of North America. Volume 1: Conifers. Volume 2: Hardwoods. Agriculture Handbook 654. U.S. Department of Agriculture, Forest Service, Washington, D.C., USA.

Clark, J. S. 1988. Effect of climate change on fire regimes in northwestern Minnesota. Nature 334:233-235.

Collatz, G. J., J. T. Ball, C. Grivet, and J. A. Berry. 1991 Physiological and environmental regulation of stomatal conductance, photosynthesis and transpiration: a model that includes a laminar boundary layer. Agricultural and Forest Meteorology 54:107-136.

Connell, J. H., and R. O. Slatyer. 1977. Mechanisms of succession in natural communities and their role in community stability and organization. American Naturalist 111:11191144.

Cramer, W., et al. 2001. Global response of terrestrial ecosystem structure and function to $\mathrm{CO}_{2}$ and climate change: results from six dynamic global vegetation models. Global Change Biology 7:357-373.

Crow, T. R. 1978. Biomass and production in three contiguous forests in northern Wisconsin. Ecology 59:265-273.
Curtis, J. T. 1959. The vegetation of Wisconsin. University of Wisconsin Press, Madison, Wisconsin, USA.

Davis, M. B. 2001. Climate change and steady state in temperate hardwood forests. Pages 211-225 in N. J. Huntly and S. Levin, editors. Ecology: achievement and challenge. Blackwell Science, Oxford, UK.

Davis, M. B., S. Sugita, R. R. Calcote, and L. E. Frelich. 1994. Historical development of alternate communities in a hemlock-hardwood forest in northern Michigan, USA. Pages 19-39 in R. May and N. R. Webb, editors. Largescale ecology and conservation biology. Blackwell Scientific Publications, Oxford, UK.

DeLucia, E. H., J. G. Hamilton, S. L. Naidu, R. B. Thomas, J. A. Andrews, A. Finzi, M. Lavine, R. Matamala, J. E. Mohan, G. R. Hendrey, and W. H. Schlesinger. 1999. Net primary production of a forest ecosystem with experimental $\mathrm{CO}_{2}$ enrichment. Science 284:1177-1179.

Ehrlen, J., and J. M. van Groenendael. 1998. The trade-off between dispersability and longevity - an important aspect of species diversity. Applied Vegetation Science 1:29-36.

Farquhar, G. D., S. von Caemmerer, and J. A. Berry. 1980. A biochemical model of photosynthetic $\mathrm{CO}_{2}$ assimilation in leaves of $\mathrm{C}_{3}$ plants. Planta 149:78-90.

Foley, J. A., I. C. Prentice, N. Ramankutty, S. Levis, D. Pollard, S. Sitch, and A. Haxeltine. 1996. An integrated biosphere model of land surface processes, terrestrial carbon balance, and vegetation dynamics. Global Biogeochemical Cycles 10:603-628

Frelich, L. E. 2002. Forest dynamics and disturbance regimes: studies from temperate evergreen-deciduous forests. Cambridge University Press, Cambridge, UK.

Frelich, L. E., R. Calcote, M. B. Davis, and J. Pastor. 1993. Patch formation and maintenance in an old-growth hemlock-hardwood forest. Ecology 74:513-527.

Frelich, L. E., and C. G. Lorimer. 1991. Natural disturbance regimes in hemlock-hardwood forests of the Upper Great Lakes region. Ecological Monographs 61:145-164.

Frissel, S. S. 1973. The importance of fire as a natural ecological factor in Itasca State Park, Minnesota. Quaternary Research 3:397-407.

Fulton, M. R. 1991. Adult recruitment as a function of juvenile growth rate in size-structured plant populations. Oikos 62:102-105.

Grigal, D. F., L. M. Chamberlain, H. R. Finney, V. Wroblewski, and E. R. Gross. 1974. Soils of the Cedar Creek Natural History Area. Miscellaneous Report 123. University of Minnesota, Agricultural Experiment Station, St. Paul, Minnesota, USA.

Grigal, D. F., and J. L. Ohmann. 1992. Carbon storage in upland forests of the Lake States. Soil Science Society of America Journal 56:935-943.

Grimm, E. C. 1984. Fire and other factors controlling the Big Woods vegetation of Minnesota in the mid-nineteenth century. Ecological Monographs 54:291-311.

Hansen, H. L., V. Kurmis, and D. D. Ness. 1974. The ecology of upland forest communities and implications for management in Itasca State Park, Minnesota. Technical Bulletin 298, Forestry Series 16. University of Minnesota, Agricultural Experiment Station, St. Paul, Minnesota, USA.

Haxeltine, A., and I. C. Prentice. 1996. BIOME3: an equilibrium terrestrial biosphere model based on ecophysiological constraints, resource availability, and competition among plant functional types. Global Biochemical Cycles 10:693-709.

Heinselman, M. L. 1973. Fire in the virgin forests of the Boundary Water Canoe Area, Minnesota. Quaternary Research 3:329-382.

Hurtt, G. C., P. R. Moorcroft, S. W. Pacala, and S. A. Levin. 1998. Terrestrial models and global change; challenges for the future. Global Change Biology 4:33-51. 
IPCC [Intergovernmental Panel on Climate Change]. 2001 Climate change 2001: the scientific basis. Contribution of the working group I to the third assessment report of the Intergovernmental Panel on Climate Change. Cambridge University Press, New York, New York, USA.

Jackson, R. B., J. Canadell, J. R. Ehrlinger, H. A. Mooney, O. E. Sala, and E. D. Schulze. 1996. A global analysis of root distributions for terrestrial biomes. Oecologia 108: 389-411.

Johnson, E. A. 1992. Fire and vegetation dynamics-studies from the North American boreal forest. Cambridge University Press, Cambridge, UK

Johnson, E. A., and S. L. Gutsell. 1994. Fire frequency models, methods and interpretations. Advances in Ecological Research 25:239-287.

Jordan, J. K. 1973. A soil resource inventory of the Sylvania Recreation Area. USDA Forest Service, Ottawa National Forest, Watersmeet, Michigan, USA.

Keyes, C., and K. L. O'Hara. 2002. Quantifying stand targets for silvicultural prevention of crown fires. Western Journal of Applied Forestry 17:101-109.

Kobe, R. S., S. W. Pacala, J. A. Silander, Jr, and C. D. Canham. 1995. Juvenile tree survivorship as a component of shade tolerance. Ecological Applications 5:517-532.

Kucharik, C. J., J. A. Foley, C. Delire, V. A. Fisher, M. T. Coe, J. D. Lenters, C. Young-Molling, N. Ramankutty, J. M. Norman, and S. T. Gower. 2000. Testing the performance of a dynamic global ecosystem model: water balance, carbon balance, and vegetation structure. Global Biogeochemical Cycles 14:795-825.

Küchler, A. W. 1964. Potential natural vegetation of the conterminous United States. Special Publication 3. American Geographical Society, New York, New York, USA.

Loehle, C., and D. LeBlanc. 1996. Model-based assessments of climate change effects on forests: a critical review. Ecological Modelling 90:1-31.

Monteith, J. L. 1995. Accomodation between transpiring vegetation and the convective boundary layer. Journal of Hydrology 166:251-263.

Moorcroft, P. R., G. C. Hurtt, and S. W. Pacala. 2001. A method for scaling vegetation dynamics: the ecosystem demography model (ED). Ecological Monographs 71:557586.

Mroz, G. D., M. R. Gale, M. F. Jurgensen, D. J. Frederick, and A. Clark. 1985. Composition, structure, and aboveground biomass of two old-growth northern hardwood stands in Upper Michigan. Canadian Journal of Forest Research 15:78-82.

Norby, R. J., K. Ogle, P. S. Curtis, F.-W. Badeck, A. Huth, G. C. Hurtt, T. Kohyama, and J. Peñuelas. 2001. Aboveground growth and competition in forest gap models: an analysis for studies of climatic change. Climatic Change 51:415-447.

Pacala, S. W., C. D. Canham, J. Saponara, J. A. Silander, Jr., R. K. Kobe, and E. Ribbens. 1996. Forest models defined by field measurements: estimation, error analysis and dynamics. Ecological Monographs 66:1-43.

Pastor, J., and M. Broschart. 1990. The spatial pattern of a northern conifer-hardwood landscape. Landscape Ecology 4:55-68.
Peterson, D. W., and P. B. Reich. 2001. Prescribed fire in oak savanna: fire frequency effects on stand structure and dynamics. Ecological Application 11:914-927.

Pickett, S. T. A., J. Kolasa, and C. G. Jones. 1994. Ecological understanding. Academic Press, San Diego, California, USA.

Prentice, I. C., M. T. Sykes, and W. Cramer. 1993. A simulation model for the transient effects of climate change on forest landscapes. Ecological Modelling 65:51-70.

Reich, P. B., D. W. Peterson, D. A. Wedin, and K. Wrage. 2001. Fire and vegetation effects on productivity and nitrogen cycling across a forest-grassland continuum. Ecology 82:1703-1719.

Reynolds, J. F., H. Bugmann, and L. F. Pitelka. 2001. How much physiology is needed in forest gap models for simulating long-term vegetation response to global change? Challenges, limitations, and potentials. Climatic Change 51:541-557.

Shugart, H. H. 1984. A theory of forest dynamics. The ecological implications of forest succession models. Springer, New York, New York, USA.

Sitch, S., B. Smith, I. C. Prentice, A. Arneth, A. Bondeau, W. Cramer, J. Kaplan, S. Levis, W. Lucht, M. Sykes, K. Thonicke, and S. Venevsky. 2003. Evaluation of ecosystem dynamics, plant geography and terrestrial carbon cycling in the LPJ dynamic global vegetation model. Global Change Biology 9:161-185.

Smith, B., I. C. Prentice, and M. T. Sykes. 2001. Representation of vegetation dynamics in the modelling of terrestrial ecosystems: comparing two contrasting approaches within European climate space. Global Ecology and Biogeography 10:621-638

Sykes, M. T., and I. C. Prentice. 1996. Climate change, tree species distributions and forest dynamics: a case study in the mixed conifers/northern hardwoods zone of northern Europe. Climatic Change 34:161-177.

Tester, J. R., A. M. Starfield, and L. E. Frelich. 1997. Modeling for ecosystem management in Minnesota pine forests. Biological Conservation 80:313-324

Thompson, R. S., K. H. Anderson, and P. J. Bartlein. 1999 Atlas of relations between climatic parameters and distributions of important trees and shrubs of North America. A. Introduction and conifers. B. Hardwoods. Professional Paper 1650 A and B. U.S. Geological Survey, Washington, D.C., USA.

Tilman, D. 1994. Competition and biodiversity in spatially structured habitats. Ecology 75:2-16.

Valentini, R., et al. 2000. Respiration as the main determinant of carbon balalance in European forests. Nature 404: 861-865.

Van Wagner, C. E. 1993. Prediction of crown fire behavior in two stands of jack pine. Canadian Journal of Forest Research 23:442-449

Watt, A. S. 1947. Pattern and process in the plant community. Journal of Ecology 35:1-22.

Westman, W. E. 1968. Invasion of fir forest by sugar maple in Itasca Park, Minnesota. Bulletin of the Torrey Botanical Club 95: $172-186$.

White, A. S. 1983. The effects of thirteen years of annual prescribed burning on a Quercus ellipsoidalis community in Minnesota. Ecology 64:1081-1085

\section{APPENDIX}

A table presenting maximum nonstressed longevity and classification into functional groups of tree species in three Great Lakes region, USA, study areas is available in ESA's Electronic Data Archive: Ecological Archives E085-011-A1. 